\title{
$\gamma$-Aminobutyric acid production and antioxidant activities in fresh cheese by Lactobacillus plantarum L10-11
}

\author{
Jirayus WORARATPHOKA ${ }^{1 *}$ (D), Sasidhorn INNOK ${ }^{1}$, Phimpha SOISUNGNOEN², Varavut TANAMOOL ${ }^{3}$, \\ Wichai SOEMPHOL ${ }^{4}$
}

\begin{abstract}
This study aimed to evaluate the $\gamma$-aminobutyric acid (GABA) production and antioxidant activity during fresh cheese processing with single and co-fermentation processes of the high-GABA producing strain, Lactobacillus plantarum L10-11. For a mini-batch of fresh cheese, milk with $0.1 \%$ monosodium glutamate was fermented for $18 \mathrm{~h}$ and GABA production was monitored by thin layer chromatography and ion chromatography. GABA could be detected in co-L10-11 at $12 \mathrm{~h}$ of fermentation and at greater amounts after $18 \mathrm{~h}$. The $18 \mathrm{~h}$ fermented milk of co-L10-11 and single-L10-11 contained GABA at 11.30 and $1.21 \mathrm{mg} / 100 \mathrm{~mL}$, respectively, while GABA was not detected in the control. After whey separation, GABA remained in the cheese curd portion, resulting in $14.91 \mathrm{mg} / 100 \mathrm{~g}$ being found in the co-L10-11 cheese curd. ABTS antioxidant and metal chelating activities significantly increased during $18 \mathrm{~h}$ of fermentation and were retained in the cheese curd in the range of 783.11-922.00 $\mu \mathrm{mol}$ TE/kg and 216.71-266.98 $\mu \mathrm{mol}$ EDTA equivalents/kg cheese, respectively. Moreover, there were no significant difference in the textural characteristic between co-L10-11 and the control cheese curd. These results suggested that Lb plantarum L10-11 could be exploited as adjunct to improve health-promoting effects of the GABA in fresh cheese.
\end{abstract}

Keywords: Lb plantarum; GABA; antioxidant activity; co-fermentation; cheese curd.

Practical Application: Lb. plantarum L10-11 has great potential as a co-starter culture by enhancing GABA content in fresh cheese which can be considered as an alternative health-promoting fermented milk product.

\section{Introduction}

Gamma-aminobutyric acid (GABA), a non-protein amino acid produced by the glutamate decarboxylation pathway, is distributed widely among microorganisms, animals and plants, and it acts as the major inhibitory neurotransmitter of the central nervous system (Wong et al., 2003). GABA possesses positive effects on stress control (Vaiva et al., 2004), has a tranquilizing effect (Pearl et al., 2006), prevents hypertension (Tsai et al., 2006), and diabetes (Hagiwara et al., 2004). Due to its physiological functions as a bioactive compound, interest in the production and comprehensive analysis of GABA has recently increased. Biosynthetic methods have focused mainly on lactic acid bacteria (LAB) because of their application in the food industry as they are considered to be GRAS (generally regarded as safe) and also as they are used as probiotics (Dhakal et al., 2012); live microorganisms which exert beneficial health effects when adequate amounts are consumed. The most interesting and practical groups of LAB which produce high levels of GABA and have been isolated include: several strains of Lactobacillus (Lb.) and Lactococcus $(L c$.), such as $L b$. plantarum from cheese (Siragusa et al., 2007) and Thai fermented fish (Tanamool et al., 2020), Lc. lactis from kimchi and yoghurt (Lu et al., 2008).
Therefore, GABA has contributed to research on the development of GABA-fortified foods such as soybean yogurt (Park \& Oh, 2007), black raspberry (Kim et al., 2009) fermented milk (yogurt) (Linares et al., 2016), and cheese (Carafa et al., 2019).

Cheese is defined as a fresh or mature product derived from milk coagulation, in which a series of biological and biochemical changes take place during the cheese-making process. It is therefore an important source of a wide range of biologically active components (Walther et al., 2008) which provide probiotic microorganisms to human intestine (Prezzi et al., 2020; Grom et al., 2020). Several bioactive compounds in cheese are derived from $\mathrm{LAB}$ metabolism which plays a crucial role during the process of cheese-making. During fermentation, starter $\mathrm{LAB}$ hydrolyses lactose to produce high amounts of lactic acid and other organic acids, while non-starter LAB (NSLAB) are responsible for the ripening process (Settanni \& Moschetti, 2010). LAB also contain proteinase enzymes that contribute to the proteolysis of cheese proteins during milk coagulation and cheese ripening, and promote the development or release of bioactive peptides, amino acids and their derivatives which

Received 26 Jan., 2021

Accepted 02 Mar., 2021

${ }^{1}$ Department of Applied Biology, Faculty of Sciences and Liberal Arts, Rajamangala University of Technology Isan, Nakhon Ratchasima, Thailand

${ }^{2}$ Department of Applied Chemistry, Faculty of Sciences and Liberal Arts, Rajamangala University of Technology Isan, Nakhon Ratchasima, Thailand

${ }^{3}$ Chemistry Program, Faculty of Science and Technology, Nakhon Ratchasima Rajabhat University, Nakhon Ratchasima, Thailand

${ }^{4}$ Fermentation Research Center for Value added Agricultural Products-FerVAAP, Department of Biotechnology, Faculty of Technology, Khon Kaen University, Khon Kaen, Thailand

*Corresponding author: jirayus.wo@rmuti.ac.th 
contribute to the development of texture and flavor in the final cheese (Leroy \& De Vuyst, 2004; Pagthinathan \& Nafees, 2015), whilst also increasing health-promoting substances (SantiagoLópez et al., 2018). Several studies have demonstrated that some of the released peptides exhibit biological properties including antioxidants (Geurts et al., 2012; Abadía-García et al., 2013), antimicrobials (Rizzello et al., 2005; Théolier et al., 2014), antiinflammatories (Sprong et al., 2010), and angiotensin-converting enzymes (ACE) (Torres-Llanez et al., 2011). Although many studies on the production of GABA and antioxidant activity of bioactive peptides generated during cheese ripening have been conducted, little work has been done on the production of these compounds in fresh cheese (Abadía-García et al., 2013; Hernández-Galán et al., 2017). Furthermore, GABA has also been detected in commercial fresh cheese at variable concentrations range of $10-900 \mathrm{mg} / \mathrm{kg}$ cheese (Diana et al., 2014). Therefore, it would be valuable to know if this type of cheese contains GABA and/or antioxidant activity so that it could potentially offer an additional food value. Previously, an isolate of $L b$. plantarum L10-11 from fermented fish (Plaa-som) has been characterized as a high-GABA producing strain which yields 5 times higher GABA content than the reference control: Thai fermented vegetables with the addition of $1 \%$ MSG (w/v) (Tanamool et al., 2020). Therefore, to assess the potential of a health-promoting cheese product, an investigation of GABA yield and antioxidant properties from the use of either a single or a co-starter culture in fresh cheese manufacturing were investigated in this study.

\section{Materials and methods}

\subsection{Bacterial strains and culture conditions}

A GABA-producing LAB strain of Lactobacillus plantarum L10-11 which was isolated from Thai fermented fish (Plaasom) in the fresh market at Nong Khai province, Thailand (Tanamool et al., 2020) was kindly obtained from Asst. Prof. Dr. Wichai Soemphol. The stock cultures were kept at $-20{ }^{\circ} \mathrm{C}$ and then streaked on MRS agar plus $0.5 \%$ calcium carbonate and anaerobically incubated at $37^{\circ} \mathrm{C}$ for $24 \mathrm{~h}$. Single colony of fresh culture was then inoculated into MRS broth and incubated at $37^{\circ} \mathrm{C}$ for $24 \mathrm{~h}$. For stock culture preparation, Lb. plantarum L10-11 was inoculated $(2 \% \mathrm{v} / \mathrm{v})$ into MRS broth and incubated at $37^{\circ} \mathrm{C}$ for $18 \mathrm{~h}$. Then the starter culture was obtained by washing with $0.9 \%$ sodium chloride solution and centrifuging at $2,000 \times \mathrm{g}$ for $5 \mathrm{~min}$. before being suspended with sterilized milk.

\subsection{Fresh cheese manufacture}

For cheese manufacture, the processing of single cream cheese was elaborated (Phadungath, 2005) in mini-cheese batches. Three mini-cheese batches (triplicate) were manufactured with different LAB cultures: fermentation by a commercial starter (control), single fermentation of $L b$. plantarum L10-11 (single-L10-11) and co-fermentation with the commercial starter and $L b$. plantarum L10-11 (co-L10-11). Whole milk (approximately 3.8\% fat content) was previously supplemented with $0.10 \%$ monosodium glutamate (MSG), pasteurized at $80{ }^{\circ} \mathrm{C}$ for $10 \mathrm{~min}$ and then cooled to $40{ }^{\circ} \mathrm{C}$. The commercial mesophilic starter cultures of $5 \mathrm{UC}$ of Lactococcus lactis spp. lactis and Lactococcus lactis spp. cremonis (Lyofast MWO030, SACCO, Italy) were used as the reference (control) for cheese production. The starter culture of Lb. plantarum L10-11 suspension (approx. $10^{10}$ cells $/ \mathrm{mL}$ ) was inoculated $(1 \% \mathrm{v} / \mathrm{v})$ with single and co-fermentation (as adjunct). Milk underwent long-set incubation at $37^{\circ} \mathrm{C}$ for $18 \mathrm{~h}$ after which the samples were collected for analysis. The curd was then cut into $1.5 \mathrm{~cm}^{3}$ cube blocks and heated at $45-50{ }^{\circ} \mathrm{C}$ for $30 \mathrm{~min}$ with gentle stirring (for more effective whey separation). Fresh cheese was obtained by allowing the whey to drain out from the curd using a muslin cloth in a vat at $4{ }^{\circ} \mathrm{C}$ overnight. After whey separation, the cheese curds were collected for analysis.

\subsection{Measurement of $\mathrm{pH}$ and Titratable Acidity (TA)}

The $\mathrm{pH}$ was measured at $25^{\circ} \mathrm{C}$ using a $\mathrm{pH}$ meter ( $\mathrm{pH}$ Master LAB, Dynamica, UK). TA was determined by titration with $0.1 \mathrm{~N} \mathrm{NaOH}$ using $9 \mathrm{~g}$ of the sample in $18 \mathrm{~mL}$ of distilled water. TA was estimated as amount of lactic acid $(\mathrm{g} / 100 \mathrm{~g})$.

\subsection{Amount of Lactic Acid Bacteria (LAB)}

The number of LAB was determined using pour plate method with MRS agar. The sample was serially diluted with $0.1 \%$ peptone solution to a suitable dilution. All samples were anaerobically incubated at $37^{\circ} \mathrm{C}$ for $24 \mathrm{~h}$. LAB viable cell count was expressed as a $\log \mathrm{CFU}$ value.

\subsection{Monitoring of GABA production by Thin Layer Chromatography (TLC)}

Qualitative detection of GABA production during 0 and $18 \mathrm{~h}$ fermentation by pre-staining TLC was conducted according to the method of Qiu et al. (2010) on a silica-gel TLC plate (SigmaAldrich Co., Germany). Milk and fermented milk extracts were prepared by protein precipitation; milk was mixed with equal volumes of $4 \%(\mathrm{w} / \mathrm{v})$ trichloroacetic acid (TCA) and allowed to stand for $10 \mathrm{~min}$ before centrifugation at $8,000 \times \mathrm{g}$ for $10 \mathrm{~min}$. $1 \mu \mathrm{L}$ of milk extract was then spotted on TLC plates (2 times) and compared with $1 \mathrm{mg} / \mathrm{L}$ of standard GABA and MSG solution. TLC plates were developed using the n-butanol: acetic acid: distilled water $(5: 3: 2, \mathrm{v} / \mathrm{v} / \mathrm{v})$ solvent mixture with $2 \%(\mathrm{w} / \mathrm{v})$ ninhydrin as the mobile phase. Then, the plate was heated at $100^{\circ} \mathrm{C}$ for $5 \mathrm{~min}$ until spots appeared.

\subsection{Quantification of GABA and glutamate by ion- chromatography}

Glutamate and GABA that accumulated in the milk, $18 \mathrm{~h}$ fermented milk or cheese curds were quantified by ion chromatography (Amino Pac PA10 column, $250 \times 2.0 \mathrm{~mm}$ i.d) with an electrochemical detector (ICS3000, Dionex). Milk and fermented milk extracts were obtained from protein precipitation by TCA according to the methods mentioned earlier. For cheese curd samples, water-soluble extracts (WSE) were prepared following the procedure of Kuchroo \& Fox (1982). Ten grams of cheese were homogenized in $20 \mathrm{~mL}$ of deionized water using a homogenizer at $6,000 \times \mathrm{g}$ for $2 \mathrm{~min}$. The homogenates were held on ice for $1 \mathrm{~h}$. Then, the WSE were obtained by centrifugation at $8,000 \times \mathrm{g}$ for $10 \mathrm{~min}$ at $4{ }^{\circ} \mathrm{C}$. Milk extract and WSE were diluted to $1: 10$ with sodium acetate buffer and filtered through $0.45 \mu \mathrm{m}$ 
nylon membrane before injection $(25 \mu \mathrm{l})$. A linear gradient profile of the mobile phase (filtered using $0.22 \mu \mathrm{m}$ nylon membranes), comprising DI water (solvent A), $250 \mathrm{mM} \mathrm{NaOH}$ (solvent B) and $1 \mathrm{M}$ sodium acetate buffer (solvent $\mathrm{C}$ ) which were: $84 \% \mathrm{~A}$ and $16 \% \mathrm{~B}(0-12 \mathrm{~min}), 68 \% \mathrm{~A}$ and $32 \% \mathrm{~B}(12-16 \mathrm{~min}), 36 \% \mathrm{~A}$, $24 \% \mathrm{~B}$, and $40 \% \mathrm{C}$ (16-40 $\mathrm{min}), 20 \% \mathrm{~A}$ and $80 \% \mathrm{~B}$ (40-42 $\mathrm{min}$ ), and $84 \% \mathrm{~A}$ and $16 \% \mathrm{~B}(42-65 \mathrm{~min})$, was applied at a flow rate of $0.25 \mathrm{~mL} / \mathrm{min}$.

\subsection{Determination of antiradical activity}

ABTS was conducted using the method of Re et al. (1999) with slight modification. The solution of 2,2'-azino-bi (3-ethylbenzothiazoline-6-sulphonic acid) diammonium salt (ABTS) was mixed with a $2.45 \mathrm{mM}$ potassium persulfate $\left(\mathrm{K}_{2} \mathrm{SO}_{4}\right)$ solution, then incubated in the dark for $12 \mathrm{~h}$. The activated ABTS solution was diluted with $0.1 \mathrm{M}$ phosphate buffer until the absorbance was $1.000 \pm 0.05$. The analysis was performed by mixing the sample of $20 \mu \mathrm{L}$ with $2 \mathrm{~mL}$ of ABTS solution, incubated in the dark at room temperature for $5 \mathrm{~min}$. The absorbance was measured at $734 \mathrm{~nm}$ by spectrophotometer. The values were compared to the Trolox standard and expressed as $\mu \mathrm{mol}$ Trolox equivalents (TE)/ L of fermented milk or $\mu \mathrm{mol} \mathrm{TE} / \mathrm{kg}$ of fresh cheese.

\subsection{Determination of metal chelating activity}

Metal (iron) chelating activity was measured as described by Chew et al. (2009) with slight modification. The solution of $0.25 \mathrm{mM}$ ferrous sulphate $(0.4 \mathrm{~mL})$ and $0.25 \mathrm{mM}$ ferrozine $(0.8 \mathrm{~mL})$ was subsequently added into $0.4 \mathrm{~mL}$ of the sample. After incubation for $10 \mathrm{~min}$, the ferrozine- $\mathrm{Fe}^{2+}$ complex formation was recorded at absorbance of $562 \mathrm{~nm}$. Chelating activity was calculated comparable to sodium EDTA standard and expressed as $\mu \mathrm{mol}$ EDTA equivalents/ L of fermented milk or $\mu$ mol EDTA equivalents/ $\mathrm{kg}$ of fresh cheese.
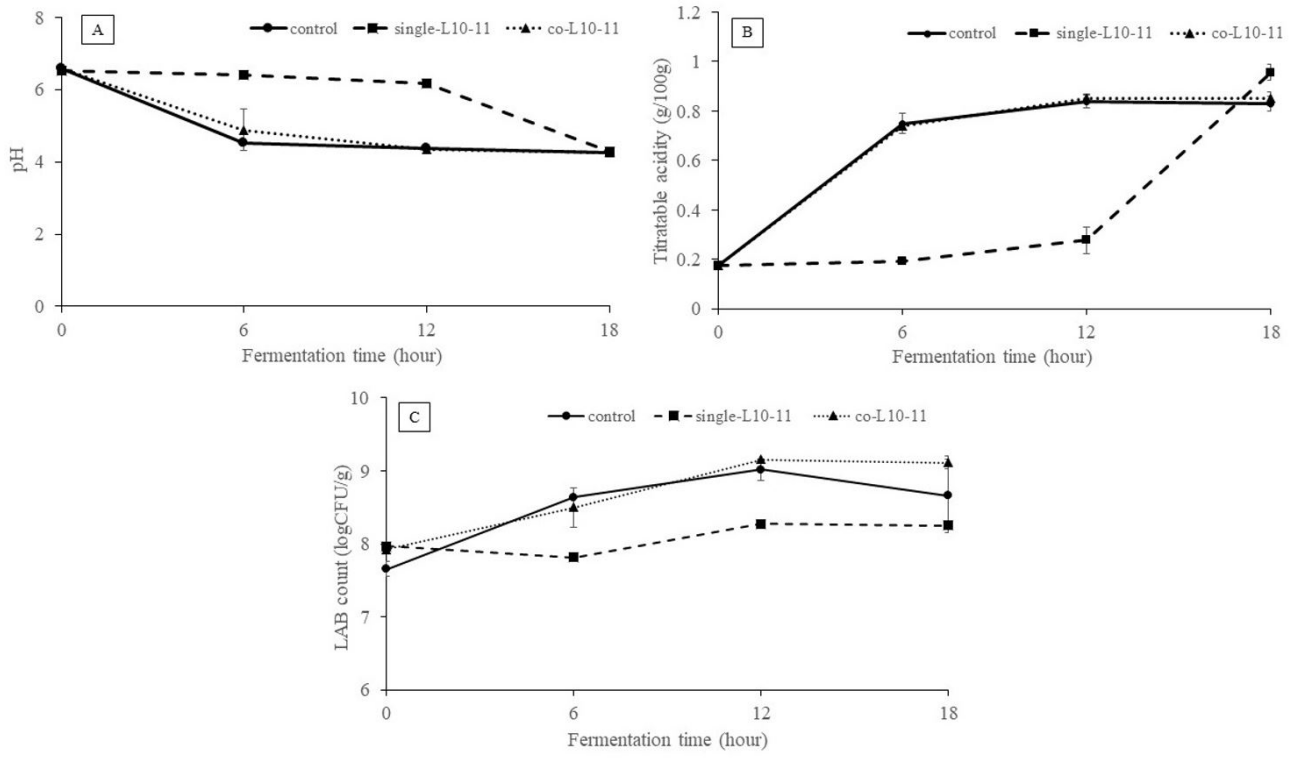

Figure 1. Changes in $\mathrm{pH}(\mathrm{A})$, titratable acidity (B), and viable lactic acid bacteria (LAB) count (C) at $18 \mathrm{~h}$ of milk fermentation; control commercial cheese starter, single-L10-11 - single fermentation of $1 \%$ Lb. plantarum, co-L10-11 - co- fermentation of $1 \%$ Lb. plantarum with commercial starter, respectively.

\subsection{Texture evaluation}

Texture evaluation of fresh cheese was performed using a CT3 Texture analyzer (Brookfiled, MA, USA). Fresh cheese curd prepared in a brick-like shape $(5 \times 5 \times 3 \mathrm{~cm})$ were wrapped in aluminum foil and kept at $4{ }^{\circ} \mathrm{C}$. A texture profile analysis (TPA) were performed at room temperature by compressing twice to $50 \%$ of their original height with a compression flat headed plunger (TA11/1000, $25.4 \mathrm{~mm}$ diameter) at a constant rate of $1 \mathrm{~mm} / \mathrm{s}$. Hardness, cohesiveness, springiness, gumminess, and chewiness were evaluated. These parameters were obtained from the Texture Pro CTV 1.8 software.

\subsection{Statistical analysis}

All investigations were performed in triplicate. Data were subjected to analysis of variance (ANOVA). Comparison of the mean values was carried out using Duncan's multiple range test (DMRT). The Statistical Package for Social Science SPSS version 22.0 (trial version) was used.

\section{Results and discussion}

\section{1 $\mathrm{pH}$ and titratable acid changes during milk fermentation}

Lb. plantarum has been detected and used as an adjunct in cheese production as a probiotic (Siragusa et al., 2007; Zhang et al., 2013). Fresh cheeses were produced according to the long-set cheese production method, which takes only 16-18 $\mathrm{h}$ for milk fermentation (milk curdling). Fermented milk, with commercial starter (control) and co-fermentation of $L b$. plantarum L10-11 (co-L10-11), resulted in a dramatic decrease of $\mathrm{pH}$ between 0-6 h, after which it gradually decreased at $12 \mathrm{~h}$ and then tended to be constant (Figure 1A). Whereas, the single fermentation by Lb. plantarum L10-11 (single-L10-11) showed a gradual decrease of $\mathrm{pH}$ after $12 \mathrm{~h}$ of fermentation. On the contrary, these changes were correlated to the changes of acid production 
(Figure 1B). The amount of titratable acid in fermented milk of the control and co-L10-11 revealed a gradual increase from $0-6 \mathrm{~h}$ (from 0.18 to $0.74 \mathrm{~g} / 100 \mathrm{~g}$ sample), then a slight increase before tending to be constant at $18 \mathrm{~h}$. While single-L10-11 did not show fast acid production, more than $0.70 \%$ of acidity increase was observed after $12 \mathrm{~h}$. However, $\mathrm{pH}$ and titratable acidity at the end of fermentation ( $18 \mathrm{~h}$ fermented milk) were not significantly different, showing the range of 4.26-4.28 and 0.83-0.96 g/100 g sample, respectively (Table 1 ).

\subsection{Kinetic growth during milk fermentation}

During milk curdling, LAB plays an important role in the hydrolysis of lactose to produce high concentrations of lactic acid and other organic acids. High amounts of LAB were in commercial and co-fermented milk (9.02 and $9.16 \mathrm{log}$ $\mathrm{CFU} / \mathrm{mL}$, respectively) which increased during the first $0-12 \mathrm{~h}$ of fermentation and slightly decreased or remained constant after that (Figure 1C). These might have contributed to the rapid decrease in $\mathrm{pH}$ (Figure 1A) and increase in titratable acid from $0-12 \mathrm{~h}$ (Figure 1B). In addition, single-L10-11 showed a continued increase in $\mathrm{LAB}$ count during $18 \mathrm{~h}$ fermentation which reached a maximum of $8.27 \log \mathrm{CFU} / \mathrm{mL}$. The constant $\mathrm{LAB}$ count in single-L10-11 and co-L10-11 after $12 \mathrm{~h}$ fermentation also indicated that $L b$. plantarum L10-11 could live under acidic conditions and play an important role during late fermentation and storage. These results revealed that the commercial starter culture, containing Lactococcus lactis spp. lactis and Lactococcus lactis spp. cremonis, might contribute to rapid acid production during the initial stages of fermentation, while $L b$. plantarum L10-11 (NSLAB) could slowly generate the acidity in fermented milk and could be used as adjunct. These results coincide with Valencia-García et al. (2018) which reported the behaviors of LAB isolated from artisanal fermented milk. The rapid acidification of Lactococcus lactis (normally used as primary culture) was detected during the first $6 \mathrm{~h}$ of incubation while slow acid production was found in Lactobacillus plantarum and highly changed after $12 \mathrm{~h}$ of incubation.

\subsection{GABA production during milk fermentation}

TLC plates were preliminarily screened for GABA production during milk fermentation. The conversion of MSG to GABA began to be observed at $12 \mathrm{~h}$ of co-L10-11 fermentation (Figure 2). Finally, the amount of GABA and glutamate in the $18 \mathrm{~h}$ fermented milk were quantified by ion chromatography. As can be seen in Table 1, co-L10-11 gave the highest GABA of $11.30 \mathrm{mg} / 100 \mathrm{~mL}$, whilst low levels were detected in singleL10-11 $(1.21 \mathrm{mg} / 100 \mathrm{~mL})$ and none in the control. Thus, this suggested that in co-L10-11 treatment, commercial culture could transform lactose to lactic acid rapidly decreasing the $\mathrm{pH}$ value to a favorable condition for glutamate decarboxylase (GAD) enzyme of $L b$. plantarum L10-11 to convert MSG to GABA as shown by the lowest amount of glutamate and the highest amount of GABA. In a previous study, it was reported that $L b$. plantarum L10-11 was clearly involved in the conversion of MSG to GABA and the highest GABA production was obtained when the initial $\mathrm{pH}$ of MRS was in the range of 5.0-6.0 (Tanamool et al., 2020). Also, the optimal $\mathrm{pH}$ for GABA production by different $\mathrm{LAB}$ strains was previously determined and mostly exhibited in the acidic pH range of 4-6 (Dhakal et al., 2012). The acidic $\mathrm{pH}$ value was also the principal regulator of GABA synthesis by inducing the GAD activity which catalyzed the conversion of L-glutamate (or its salts) into GABA through a single step of a-decarboxylation (Battaglioli et al., 2003). Therefore, cofermentation of the commercial culture and $L b$. plantarum L10-11 could possibly increase the rate of the GABA production.

Table 1. Chemical properties of the initial milk and $18 \mathrm{~h}$ fermented milk with single and co-fermentation of Lb. plantarum L10-11.

\begin{tabular}{|c|c|c|c|c|}
\hline \multirow{2}{*}{ Analysis } & \multirow{2}{*}{ Initial (0h) } & \multicolumn{3}{|c|}{$18 \mathrm{~h}$ fermented milk } \\
\hline & & control & Single-L10-11 & Co-L10-11 \\
\hline $\mathrm{pH}$ & $6.56 \pm 0.02$ & $4.27 \pm 0.06^{\mathrm{ns}}$ & $4.28 \pm 0.07^{\mathrm{ns}}$ & $4.26 \pm 0.01^{\mathrm{ns}}$ \\
\hline Titratable acid (g/100 g) & $0.17 \pm 0.01$ & $0.83 \pm 0.03^{b}$ & $0.96 \pm 0.03^{\mathrm{a}}$ & $0.85 \pm 0.03^{\mathrm{b}}$ \\
\hline GABA $(\mathrm{mg} / 100 \mathrm{~mL})$ & ND & ND & $1.21 \pm 0.08^{\mathrm{b}}$ & $11.30 \pm 1.48^{\mathrm{a}}$ \\
\hline Glutamate $(\mathrm{mg} / 100 \mathrm{~mL})$ & $26.74 \pm 1.55$ & $25.94 \pm 1.37^{\mathrm{a}}$ & $14.43 \pm 1.38^{\mathrm{b}}$ & $11.21 \pm 1.71^{\mathrm{c}}$ \\
\hline ABTS $(\mu \mathrm{mol} \mathrm{TE} / \mathrm{L})$ & $263.78 \pm 35.03$ & $976.00 \pm 14.81^{\mathrm{a}}$ & $634.89 \pm 108.73^{\mathrm{b}}$ & $898.78 \pm 105.01^{\mathrm{a}}$ \\
\hline $\begin{array}{l}\text { Metal chelating } \\
(\mu \mathrm{mol} \text { EDTA/L) }\end{array}$ & $118.72 \pm 17.42$ & $172.08 \pm 25.68^{\text {ns }}$ & $153.56 \pm 27.05^{\mathrm{ns}}$ & $150.05 \pm 21.82^{\mathrm{ns}}$ \\
\hline
\end{tabular}

${ }_{\mathrm{a}-\mathrm{c}}$ Values in the same row with different letters are significantly different $(\mathrm{p} \leq 0.05) .{ }^{\text {ns }}$ Values in the same row are not significantly different $(\mathrm{p}>0.05)$. ND $=$ not detected.

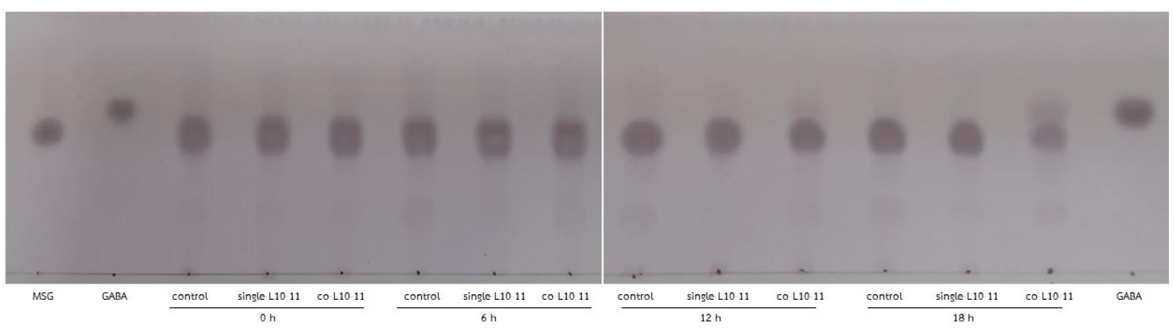

Figure 2. TLC chromatogram of GABA and glutamate changes during $18 \mathrm{~h}$ milk fermentation with single and co-fermentation of $L b$. plantarum L10-11. 
The addition of MSG, the flavor enhancer, might have an influence on the sensory profile (umami taste) of fresh cheese. Normally free glutamic acid, during cheese age, has been found in some cheese (Cheddar, Emmental and Parmigiano Reggiano cheese) and is concurrent with the increase in umami intensities (Weaver \& Kroger, 1978; Ninomiya, 1998). Furthermore, the MSG is an alternative for reducing the sodium content in food and also cheese (Rodrigues et al., 2014), since it contains approximately $13 \%$ sodium which is less than half of the sodium contained in $\mathrm{NaCl}$. Sodium reduction with flavor enhancer addition (arginine, yeast extract, oregano extract, MSG) contributed to sensory profile in cheese (Silva et al., 2018; Rodrigues et al., 2014). Therefore, the remaining glutamic acid and also sodium might affect the sensory profile of cheese whereby optimized intense research should be done in further study.

\subsection{Antiradical and iron chelating activities during milk fermentation}

The occurrence of ABTS radical scavenging of milk significantly increased after milk fermentation. ABTS radical scavenging of the control and co-L10-11 (ranged from 898.78-976.00 $\mu \mathrm{mol} \mathrm{TE/L)}$ were significantly higher than that of single-L10-11 $(634.89 \mu \mathrm{mol}$ TE/L) (Table 1) while no DPPH radical scavenging ability were detected in any of $18 \mathrm{~h}$ fermented milk (data not shown). The different actions associated with the same sample with the two testing methods might be attributed to the different structures of the radicals that may behave differently based on the peptides present in the sample (Abadía-García et al., 2013). Moreover, the ABTS assay is applicable to both hydrophilic and lipophilic antioxidant systems and better estimates the antioxidant ability of food items (Floegel et al., 2011) and is also more compatible to the water-soluble substances in curded milk.

The development of iron chelating activity also increased during fermentation but was not significantly different between the three sets of the fermented milk which ranged from 150.05-172.08 $\mu \mathrm{mol}$ EDTA equivalent/L. As similarly to Abubakr et al. (2012) findings which showed an increase in ferrous chelating activity of whey from a $24 \mathrm{~h}$ fermented milk which was incubated with LAB isolates from different food samples as compared to the milk control. The initial iron-chelating activity in this study was $118.72 \mu \mathrm{mol}$ EDTA equivalent/L, which was due to the ability of certain milk proteins (such as lactoferrin serum albumin and casein) to bind with iron (Tong et al., 2000). On the other hand, the peptides generated during fermentation which might contain more of phosphoryl serine groups or the carboxyl group of the amino acids asparagine and glutamine have a higher propensity for iron-binding (Wong and Kitts, 2003).

During milk coagulation, the action of milk enzymes and enzymes from the culture starter proteolyse milk proteins (caseins) into polypeptides or several fractions of peptides. Some peptides are bioactive and play an important role in health benefits such as antioxidant activity and antihypertension (Torres-Llanez et al., 2011; Geurts et al., 2012; Abadía-García et al., 2013). Therefore, the enzymes in milk as well as the enzymes from the commercial starter or Lb. plantarum L10-11 might contribute to the proteolysis of casein protein during milk coagulation and might increase the antioxidant properties of fermented milk. In cheese production, antioxidant activity has been reported to mainly depend on ripening time (Gupta et al., 2009). However, there are several studies indicating that the antioxidant peptides are released not only during ripening but also during cheese making (coagulation step) (Hernández-Galán et al., 2017; Abadía-García et al., 2013). The difference in antioxidant activity can be ascribed to the diverse hydrolysates in cheese by distinctive LAB strains as each strain of LAB has proteases which account for the cleavage into specific peptides. This cleavage forms peptides with varying antioxidant capacities due to peptide structure, arrangement of the amino acids within the structure, and size of the peptide (Tagliazucchi et al., 2019; Mushtaq et al., 2016).

\subsection{Chemical properties of fresh cheese curd}

After coagulation, the curds were cut, cooked, and drained in muslin cloth overnight; the appearance of fresh cheese is shown in Figure 3. All mini batch fresh cheese had a moisture content range of 74.07-74.90\% with a $\mathrm{pH}$ range of 4.17-4.37. After whey separation, the amount of GABA in Co-L10-11 and single-L10-11 fresh cheese remained at 14.91 and $2.48 \mathrm{mg} / 100 \mathrm{~g}$, respectively, as shown in Table 2 . The WSE portion of cheese which might have consisted of peptides also had the ability to scavenge free radicals and iron chelating activities which ranged from $783.11-922.00 \mu \mathrm{mol} \mathrm{TE} / \mathrm{kg}$ of cheese and 216.71-266.98 $\mu \mathrm{mol}$ EDTA equivalent/kg of cheese, respectively. This result implied that GABA as well as bioactive peptides, which are water-soluble substances, still existed during whey separation process in fresh cheese.

The GABA content of 34 types of artisanal Spanish cheese showed an average of $330 \mathrm{mg} / \mathrm{kg}$ which were not influenced by ripening stage or milk source (Diana et al., 2014). Among these, the GABA content of three types of fresh cheeses ranged between $10-900 \mathrm{mg} / \mathrm{kg}$. To date, studies on the production of GABA in cheese are mainly in ripened cheese. Other studies have reported the presence of GABA in laboratory cheddar cheese cultured with Lactococcus lactis ssp. lactis 712 which was as high as $383.2 \mu \mathrm{g} / \mathrm{g}$ cheese and also in some varieties of commercial cheese: Gouda, Cheddar, Blue and Edam chesses of $177,48,7.1$, and $4.2 \mu \mathrm{g} / \mathrm{g}$ cheese, respectively (Nomura et al., 1998). Carafa et al. (2019) showed an increase in GABA during ripening, with the highest content occurring in $S$. thermophiles $84 \mathrm{C}$ after 9 days of ripening $(84 \pm 37 \mathrm{mg} / \mathrm{kg})$ and in co-fermentation of S. thermophiles $84 \mathrm{C}-$ Lb. brevis DSM 32386 and commercial S. thermophiles - Lb. brevis DSM 32386 after 20 days of ripening (91 \pm 28 and $88 \pm 24 \mathrm{mg} / \mathrm{kg}$ ), respectively.

In both animal and human studies, several researches have demonstrated the reduction of high blood pressure effects of GABA (Diana et al., 2014). In clinical trials, a treatment with $100 \mathrm{~mL}$ of fermented milk (10-12 mg of GABA content) or $50 \mathrm{~g}$ of GABA-enriched cheese ( $16 \mathrm{mg}$ of GABA) for 12 weeks, could reduce blood pressure in hypertensive patients (Inoue et al., 2003; Pouliot-Mathieu et al., 2013). In the present study, the co-fermented L10-11 cheese (with addition of $0.1 \%$ monosodium glutamate) contained GABA levels of $14.91 \mathrm{mg} / 100 \mathrm{~g}$, which is about half of the health's recommendation. However, it is comparable to the other GABA cheese and covering the total intake required to perceive positive effects on human wellbeing. 


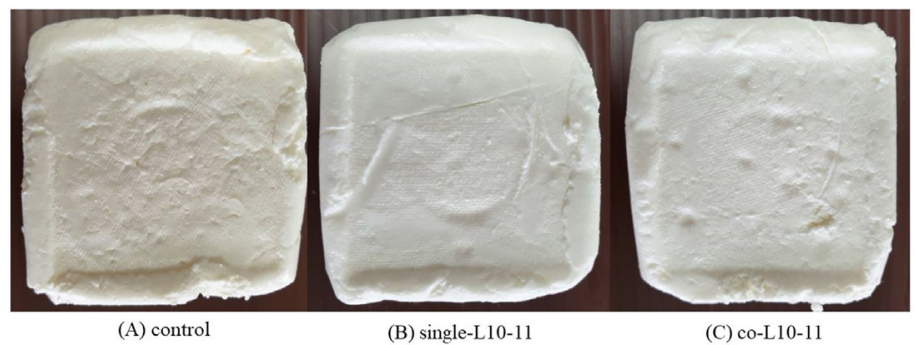

Figure 3. Appearance of fresh cheese curd fermented with commercial starter, control (A), single (B) and co-fermentation of $L b$. plantarum L10-11 (C).

Table 2. Chemical properties of fresh cheese curd with single and co-fermentation of Lb. plantarum L10-11.

\begin{tabular}{|c|c|c|c|}
\hline \multirow{2}{*}{ Analysis } & \multicolumn{3}{|c|}{ Cheese } \\
\hline & Control & Single-L10-11 & Co-L10-11 \\
\hline $\mathrm{pH}^{\mathrm{ns}}$ & $4.37 \pm 0.01$ & $4.17 \pm 0.05$ & $4.29 \pm 0.07$ \\
\hline Moisture content $^{\mathrm{ns}}$ & $74.90 \pm 0.66$ & $74.72 \pm 0.73$ & $74.07 \pm 0.78$ \\
\hline GABA (mg/100 g) & ND & $2.48 \pm 0.37^{\mathrm{b}}$ & $14.91 \pm 0.07^{\mathrm{a}}$ \\
\hline Glutamate (mg/100 g) & $14.25 \pm 1.79^{\mathrm{a}}$ & $7.91 \pm 0.48^{\mathrm{a}}$ & $2.61 \pm 1.02^{\mathrm{b}}$ \\
\hline ABTS $(\mu \mathrm{molTE} / \mathrm{kg})^{\mathrm{ns}}$ & $922.00 \pm 96.15$ & $783.11 \pm 87.71$ & $872.00 \pm 31.80$ \\
\hline Metal chelating ( $\mu \mathrm{mol}$ EDTA/kg) & $261.11 \pm 24.95^{\mathrm{a}}$ & $216.71 \pm 7.03^{\mathrm{b}}$ & $266.98 \pm 26.25^{\mathrm{a}}$ \\
\hline
\end{tabular}

a-bValues in the same row with different letters are significantly different $(\mathrm{p} \leq 0.05)$. ns Values in the same row are not significantly different $(\mathrm{p}>0.05)$. ND $=$ not detected.

Table 3. Textural profile of fresh cheese curd with single and co-fermentation of Lb. plantarum L10-11.

\begin{tabular}{|c|c|c|c|}
\hline \multirow{2}{*}{ Texture profile } & \multicolumn{3}{|c|}{ Cheese } \\
\hline & Control & Single-L10-11 & Co-L10-11 \\
\hline Hardness (N) & $3.65 \pm 0.13^{\mathrm{a}}$ & $2.64 \pm 0.26^{\mathrm{b}}$ & $2.92 \pm 0.44^{\mathrm{b}}$ \\
\hline Adhesiveness $(\mathrm{mJ})^{\mathrm{ns}}$ & $2.43 \pm 1.30$ & $2.10 \pm 1.82$ & $1.93 \pm 1.11$ \\
\hline Cohesiveness $^{\text {ns }}$ & $0.14 \pm 0.03$ & $0.14 \pm 0.03$ & $0.18 \pm 0.01$ \\
\hline Springiness $(\mathbf{m m})^{\mathrm{ns}}$ & $4.66 \pm 0.84$ & $3.83 \pm 0.85$ & $4.08 \pm 0.31$ \\
\hline Chewiness $(\mathrm{mJ})^{\mathrm{ns}}$ & $1.93 \pm 0.45$ & $1.40 \pm 0.10$ & $1.60 \pm 0.28$ \\
\hline Gumminess $(\mathrm{N})^{\mathrm{ns}}$ & $0.41 \pm 0.08$ & $0.37 \pm 0.05$ & $0.42 \pm 0.09$ \\
\hline
\end{tabular}

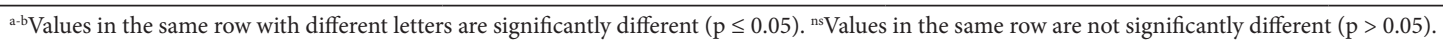

Moreover, the antioxidant properties from bioactive peptides in cheese might enhance the health-promoting ability of these fresh cheeses.

\subsection{Texture of fresh cheese curd}

The appearance and textural profile of cheese curds are shown in Figure 3 and Table 3. Fresh cheese curd produced by single and co-fermentation exhibited significantly lower values of hardness $(p \leq 0.05)$ compared to the control cheese curd. However, the adhesiveness, cohesiveness, springiness, chewiness, and gumminess values did not differ significantly ( $p>0.05$ ) among the tested cheese curd. The results confirm that adding $L b$. plantarum L10-11 does not have much effect on the textural properties of cheese curd.

\section{Conclusions}

The data obtained in this study demonstrated that cofermentation of commercial cheese starter with $\mathrm{Lb}$. plantarum L10-11 enhanced GABA content significantly. The chemical and textural properties obtained from co-fermentation was comparable to the commercial one. This may impact on the satisfaction of consumer, therefore, the sensory test needs to be conducted in future. These results have confirmed that $L b$. plantarum L10-11 might be exploited as bio-functional adjunct cultures for promoting GABA biosynthesis in fresh cheese, and should be considered as alternative health promoting product.

\section{Acknowledgements}

The authors wish to thank Kongpop Pengsantia, Pawan Paha, and Chet Mat, the senior project students who provided the experimental data. Thank you to the School of Applied Biology, Faculty of Sciences and Liberal Arts, and the Research and Development Institute, Rajamangala University of Technology Isan that provided valuable laboratory support and research equipment. We would also like to thank Ms. Martha Maloi Eromine for the support in editing English language in this manuscript.

\section{References}

Abadía-García, L., Cardador, A., Martín del Campo, S. T., Arvízu, S. M., Castaño-Tostado, E., Regalado-González, C., García-Almendarez, B., \& Amaya-Llano, S. L. (2013). Influence of probiotic strains added 
to cottage cheese on generation of potentially antioxidant peptides, anti-listerial activity, and survival of probiotic microorganisms in simulated gastrointestinal conditions. International Dairy Journal, 33(2), 191-197. http://dx.doi.org/10.1016/j.idairyj.2013.04.005.

Abubakr, M. A. S., Hassan, Z., Imdakim, M. M. A., \& Sharifah, N. R. S. A. (2012). Antioxidant activity of lactic acid bacteria (LAB) fermented skim milk as determined by 1,1-diphenyl-2-picrylhydrazyl (DPPH) and ferrous chelating activity (FCA). African Journal of Microbiological Research, 6(34), 6358-6364. http://dx.doi.org/10.5897/AJMR12.702.

Battaglioli, G., Liu, H., \& Martin, D. L. (2003). Kinetic differences between the isoforms of glutamate decarboxylase: implications for the regulation of GABA synthesis. Journal of Neurochemistry, 86(4), 879-887. http://dx.doi.org/10.1046/j.1471-4159.2003.01910.x. PMid:12887686.

Carafa, I., Stocco, G., Nardin, T., Larcher, R., Bittante, G., Tuohy, K., \& Franciosi, E. (2019). Production of naturally $\gamma$-aminobutyric acidenriched cheese using the dairy strains Streptococcus thermophilus 84C and Lactobacillus brevis DSM 32386. Frontiers in Microbiology, 10, 93-103. http://dx.doi.org/10.3389/fmicb.2019.00093. PMid:30814980.

Chew, Y.-L., Goh, J.-K., \& Lim, Y.-Y. (2009). Assessment of in vitro antioxidant capacity and polyphenolic composition of selected medicinal herbs from Leguminosae family in Peninsular Malaysia. Food Chemistry, 116(1), 13-18. http://dx.doi.org/10.1016/j. foodchem.2009.01.091.

Dhakal, R., Bajpai, V. K., \& Baek, K. H. (2012). Production of GABA ( $\gamma$-aminobutyric acid) by microorganisms: a review. Brazilian Journal of Microbiology, 43(4), 1230-1241. http://dx.doi.org/10.1590/S151783822012000400001. PMid:24031948.

Diana, M., Rafecas, M., Arco, C., \& Quilez, J. (2014). Free amino acid profile of Spanish artisanal cheeses: Importance of gammaaminobutyric acid (GABA) and ornithine content. Journal of Food Composition and Analysis, 35(2), 94-100. http://dx.doi.org/10.1016/j. jfca.2014.06.007.

Floegel, A., Kim, D.-O., Chung, S.-J., Koo, S. I., \& Chun, O. K. (2011). Comparison of ABTS/DPPH assays to measure antioxidant capacity in popular antioxidant-rich US foods. Journal of Food Composition and Analysis, 24(7), 1043-1048. http://dx.doi.org/10.1016/j. jfca.2011.01.008.

Geurts, L., Everard, A., le Ruyet, P., Delzenne, N. M., \& Cani, P. D. (2012). Ripened dairy products differentially affect hepatic lipid content and adipose tissue oxidative stress markers in obese and type 2 diabetic mice. Journal of Agricultural and Food Chemistry, 60(8), 2063-2068. http://dx.doi.org/10.1021/jf204916x. PMid:22300436.

Grom, L. C., Rocha, R. S., Balthazar, C. F., Guimarães, J. T., Coutinho, N. M., Barros, C. P., Pimentel, T. C., Venáncio, E. L., Collopy, I. Jr., Maciel, P. M. C., Silva, P. H. F., Granato, D., Freitas, M. Q., Esmerino, E. A., Silva, M. C., \& Cruz, A. G. (2020). Postprandial glycemia in healthy subjects: Which probiotic dairy food is more adequate? Journal of Dairy Science, 103(2), 1110-1119. http://dx.doi.org/10.3168/ jds.2019-17401. PMid:31785881.

Gupta, A., Mann, B., Kumar, R., \& Sangwan, R. B. (2009). Antioxidant activity of Cheddar cheeses at different stages of ripening. International Journal of Dairy Technology, 62(3), 339-347. http:// dx.doi.org/10.1111/j.1471-0307.2009.00509.x.

Hagiwara, H., Seki, T., \& Ariga, T. (2004). The effect of pre-germinated brown rice intake on blood glucose and PAI-1 levels in streptozotocininduced diabetic rats. Bioscience, Biotechnology, and Biochemistry, 68(2), 444-447. http://dx.doi.org/10.1271/bbb.68.444. PMid:14981313.

Hernández-Galán, L., Cardador-Martínez, A., López-delCastillo, M., Picque, D., Spinnler, H. E., \& Martín del Campo, S. T. (2017). Antioxidant and angiotensin-converting enzyme inhibitory activity in fresh goat cheese prepared without starter culture: a preliminary study. CYTA: Journal of Food, 15(1), 49-57. http://dx.doi.org/10.10 80/19476337.2016.1202325.

Inoue, K., Shirai, T., Ochiai, H., Kasao, M., Hayakawa, K., Kimura, M., \& Sansawa, H. (2003). Blood-pressure-lowering effect of a novel fermented milk containing g-aminobutyric acid (GABA) in mild hypertensives. European Journal of Clinical Nutrition, 57(3), 490495. http://dx.doi.org/10.1038/sj.ejcn.1601555. PMid:12627188.

Kim, J. Y., Lee, M. Y., Ji, G. E., Lee, Y. S., \& Hwang, K. T. (2009). Production of $\gamma$-aminobutyric acid in black raspberry juice during fermentation by Lactobacillus brevis GABA100. International Journal of Food Microbiology, 130(1), 12-16. http://dx.doi.org/10.1016/j. ijfoodmicro.2008.12.028. PMid:19167126.

Kuchroo, C. N., \& Fox, P. F. (1982). Soluble nitrogen in Cheddar cheese: comparison of extraction procedures. Milchwissenschaft. Milk Science International, 37(6), 331-335.

Leroy, F., \& De Vuyst, L. (2004). Lactic acid bacteria as functional starter cultures for the food fermentation industry. Trends in Food Science \& Technology, 15(2), 67-78. http://dx.doi.org/10.1016/j. tifs.2003.09.004.

Linares, D. M., O'Callaghan, T. F., O'Connor, P. M., Ross, R. P., \& Stanton, C. (2016). Streptococcus thermophilus APC151 strain is suitable for the manufacture of naturally GABA-enriched bioactive yogurt. Frontiers in Microbiology, 7, 1876-1884. http://dx.doi.org/10.3389/ fmicb.2016.01876. PMid:27920772.

Lu, X., Chen, Z., Gu, Z., \& Han, Y. (2008). Isolation of $\gamma$-aminobutyric acid producing bacteria and optimization of fermentative medium. Biochemical Engineering Journal, 41(1), 48-52. http://dx.doi. org/10.1016/j.bej.2008.03.005.

Mushtaq, M., Gani, A., Masoodi, F. A., \& Ahmad, M. (2016). Himalayan cheese (Kalari/Kradi) Effect of different probiotic strains on oxidative stability, microbiological, sensory and nutraceutical properties during storage. Lebensmittel-Wissenschaft + Technologie, 67, 74-81. http:// dx.doi.org/10.1016/j.lwt.2015.11.039.

Ninomiya, K. (1998). Natural occurrence. Food Reviews International, 14(2\&3), 177-211. http://dx.doi.org/10.1080/87559129809541157.

Nomura, M., Kimoto, H., Someya, Y., Furukawa, S., \& Suzuki, I. (1998). Production of g-aminobutyric acid by cheese starters during cheese ripening. Journal of Dairy Science, 81(6), 1486-1491. http://dx.doi. org/10.3168/jds.S0022-0302(98)75714-5. PMid:9684157.

Pagthinathan, M., \& Nafees, M. S. M. (2015). Biochemistry of cheese ripening. Journal of Agricultural Sciences, 10, 16-26. http://dx.doi. org/10.4038/agrieast.v10i0.25.

Park, K. B., \& Oh, S. H. (2007). Production of yogurt with enhanced levels of gamma-aminobutyric acid and valuable nutrients using lactic acid bacteria and germinated soybean extracts. Bioresource Technology, 98(8), 1675-1679. http://dx.doi.org/10.1016/j.biortech.2006.06.006. PMid:17055264.

Pearl, P. L., Hartka, T. R., Cabalza, J. L., Taylor, J., \& Gibson, M. K. (2006). Inherited disorders of GABA metabolism. Future Neurology, 1(5), 631-636. http://dx.doi.org/10.2217/14796708.1.5.631. PMid:23842532.

Phadungath, C. (2005). Cream cheese products: a review. Songklanakarin Journal of Science and Technology, 27(1), 191-199. Retrieved from https://rdo.psu.ac.th/sjstweb/journal/27-1/18cream-cheese.pdf

Pouliot-Mathieu, K., Gardner-Fortier, C., Lemieux, S., St-Gelais, D., Champagne, C. P., \& Vuillemard, J.-C. (2013). Effect of cheese containing gamma-aminobutyric acid-producing lactic acid bacteria on blood pressure in men. PharmaNutrition, 1(4), 141-148. http:// dx.doi.org/10.1016/j.phanu.2013.06.003. 
Prezzi, L. E., Lee, S. H. I., Nunes, V. M. R., Corassin, C. H., Pimentel, T. C., Rocha, R. S., Ramos, G. L. P. A., Guimarães, J. T., Balthazar, C. F., Duarte, M. C. K. H., Freitas, M. Q., Esmerino, E. A., Silva, M. C., Cruz, A. G., \& Oliveira, C. A. F. (2020). Effect of Lactobacillus rhamnosus on growth of Listeria monocytogenes and Staphylococcus aureus in a probiotic Minas Frescal cheese. Food Microbiology, 92, 103557-103562. http://dx.doi.org/10.1016/j.fm.2020.103557. PMid:32950151.

Qiu, T., Li, H., \& Cao, Y. (2010). Pre-staining thin layer chromatography method for amino acid detection. African Journal of Biotechnology, 9(50), 8679-8681. http://dx.doi.org/10.5897/AJB10.817.

Re, R., Pellegrini, N., Proteggente, A., Pannala, A., Yang, M., \& RiceEvans, C. (1999). Antioxidant activity applying an improved ABTS radical cation decolorization assay. Free Radical Biology \& Medicine, 26(9-10), 1231-1237. http://dx.doi.org/10.1016/S0891-5849(98)003153. PMid:10381194.

Rizzello, C. G., Losito, I., Gobbetti, M., Carbonara, T., De Bari, M. D., \& Zambonin, P. G. (2005). Antibacterial activities of peptide from the water-soluble extracts of Italian cheese varieties. Journal of Dairy Science, 88(7), 2348-2360. http://dx.doi.org/10.3168/jds. S0022-0302(05)72913-1. PMid:15956298.

Rodrigues, J. F., Goncalves, C. S., Pereira, R. C., Carneiro, J. D. S., \& Pinheiro, A. C. M. (2014). Utilization of temporal dominance of sensations and time intensity methodology for development of low-sodium Mozzarella cheese using a mixture of salts. Journal of Dairy Science, 97(8), 4733. http://dx.doi.org/10.3168/jds.2014-7913. PMid:24881790.

Santiago-López, L., Aguilar-Toalá, J. E., Hernández-Mendoza, A., Vallejo-Cordoba, B., Liceaga, A. M., \& González-Córdova, A. F. (2018). Invited review: Bioactive compounds produced during cheese ripening and health effects associated with aged cheese consumption. Journal of Dairy Science, 101(5), 3742-3757. http:// dx.doi.org/10.3168/jds.2017-13465. PMid:29477517.

Settanni, L., \& Moschetti, G. (2010). Non-starter lactic acid bacteria used to improve cheese quality and provide health benefits. Food Microbiology, 27(6), 691-697. http://dx.doi.org/10.1016/j. fm.2010.05.023. PMid:20630311.

Silva, H. L. A., Balthazar, C. F., Silva, R., Vieira, A. H., Costa, R. G. B., Esmerino, E. A., Freitas, M. Q., \& Cruz, A. G. (2018). Sodium reduction and flavor enhancer addition in probiotic prato cheese: contributions of quantitative descriptive analysis and temporal dominance of sensations for sensory profiling. Journal of Dairy Science, 101(10), 8837-8846. http://dx.doi.org/10.3168/jds.201814819. PMid:30077456.

Siragusa, S., De Angelis, M., Di Cagno, R., Rizzello, C. G., Coda, R., \& Gobbetti, M. (2007). Synthesis of g-aminobutyric acid by lactic acid bacteria isolated from a variety of Italian cheeses. Applied and Environmental Microbiology, 73(22), 7283-7290. http://dx.doi. org/10.1128/AEM.01064-07. PMid:17890341.

Sprong, R. C., Schonewille, A. J., \& van der Meer, R. (2010). Dietary cheese whey protein protects rats against mild dextran sulfate sodium-induced colitis: Role of mucin and microbiota. Journal of Dairy Science, 93(4), 1364-1371. http://dx.doi.org/10.3168/jds.20092397. PMid:20338413.

Tagliazucchi, D., Martini, S., \& Solieri, L. (2019). Review: Bioprospecting for bioactive peptide production by lactic acid bacteria isolated from fermented dairy food. Fermentation, 5(4), 96-129. http://dx.doi. org/10.3390/fermentation5040096.

Tanamool, V., Hongsachart, P., \& Soemphol, W. (2020). Screening and characterisation of gamma-aminobutyric acid (GABA) producing lactic acid bacteria isolated from Thai fermented fish (Plaa-som) in Nong Khai and its application in Thai fermented vegetables (Sompak). Food Science and Technology, 40(2), 483-490. http://dx.doi. org/10.1590/fst.05419.

Théolier, J., Hammami, R., Fliss, I., \& Jean, J. (2014). Antibacterial and antifungal activity of water-soluble extracts from Mozzarella, Gouda, Swiss, and Cheddar commercial cheeses produced in Canada. Dairy Science \& Technology, 94(5), 427-438. http://dx.doi.org/10.1007/ s13594-014-0170-9.

Tong, L. M., Sasaki, S., McClements, D. J., \& Decker, E. A. (2000). Mechanisms of the antioxidant activity of a high molecular weight fraction of whey. Journal of Agricultural and Food Chemistry, 48(5), 1473-1478. http://dx.doi.org/10.1021/jf991342v. PMid:10820045.

Torres-Llanez, M. J., González-Córdova, A. F., Hernández-Mendoza, A., García, H. S., \& Vallejo-Córdoba, B. (2011). Angiotensin-converting enzyme inhibitory activity in Mexican Fresco cheese. Journal of Dairy Science, 94(8), 3794-3800. http://dx.doi.org/10.3168/jds.2011-4237. PMid:21787916.

Tsai, J. S., Lin, Y. S., Pan, B. S., \& Chen, T. J. (2006). Antihypertensive peptides and $\gamma$-aminobutyric acid from prozyme 6 facilitated lactic acid bacteria fermentation of soymilk. Process Biochemistry, 41(6), 1282-1288. http://dx.doi.org/10.1016/j.procbio.2005.12.026.

Vaiva, G., Thomas, P., Ducrocq, F., Fontaine, M., Boss, V., Devos, P., Rascle, C., Cottencin, O., Brunet, A., Laffargue, P., \& Goudemand, M. (2004). Low posttrauma GABA plasma levels as a predictive factor in the development of acute posttraumatic stress disorder. Biological Psychiatry, 55(3), 250-254. http://dx.doi.org/10.1016/j. biopsych.2003.08.009. PMid:14744465.

Valencia-García, F. E., Motato-Rocha, K. E., Vera-Peña, M. Y., \& Sepúlveda-Lindarte, M. L. (2018). Kinetic parameters of lactic acid bacterial isolated from fermented milk "Suero Costeño". Dyna (Bilbao), 85(206), 155-161. http://dx.doi.org/10.15446/dyna.v85n206.70995.

Walther, B., Schmid, A., Sieber, R., \& Wehrmüller, K. (2008). Cheese in nutrition and health. Dairy Science \& Technology, 88(4), 389-405. http://dx.doi.org/10.1051/dst:2008012.

Weaver, J. C., \& Kroger, M. (1978). Free amino acid and rheological measurements on hydrolyzed lactose cheddar cheese during ripening. Journal of Food Science, 43, 579-583. http://dx.doi. org/10.1111/j.1365-2621.1978.tb02359.x.

Wong, C. G., Bottiglieri, T., \& Carter Snead, O. 3rd (2003). GABA, $\gamma$-hydroxybutyric acid, and neurological disease. Annals of Neurology, 54(Suppl.6), S3-S12. http://dx.doi.org/10.1002/ana.10696. PMid:12891648.

Wong, P., \& Kitts, D. (2003). Chemistry of butter milk solid antioxidant activity. Journal of Dairy Science, 86(5), 1541-1547. http://dx.doi. org/10.3168/jds.S0022-0302(03)73739-4. PMid:12778564.

Zhang, L., Zhang, X., Liu, C., Li, C., Li, S., Li, T., Li, D., Zhao, Y., \& Yang, Z. (2013). Manufacture of Cheddar cheese using probiotic Lactobacillus plantarum K25 and its cholesterol-lowering effects in a mice model. World Journal of Microbiology \& Biotechnology, 29(1), 127-135. http://dx.doi.org/10.1007/s11274-012-1165-4. PMid:22956024. 